\title{
PENGAMANAN BARANG MILIK DAERAH DALAM MEWUJUDKAN AKUNTABILITAS DI BPKAD KOTA MADIUN
}

\author{
Anggie Riestanty ${ }^{1}$ \\ Pendidikan Akuntansi FKIP \\ Universitas PGRI Madiun \\ anggie.sudjiono@gmail.com
}

\author{
Isharijadi $^{2}$ \\ Pendidikan Akuntansi FKIP \\ Universitas PGRI Madiun \\ isharijadi57@gmail.com
}

\author{
Juli Murwani ${ }^{3}$ \\ Pendidikan Akuntansi FKIP \\ Universitas PGRI Madiun \\ jmurwani@unipma.ac.id
}

\begin{abstract}
ABSTRAK
Penelitian ini bertujuan untuk menganalisis dan menjabarkan bagaimana pelaksanaan pengamanan Barang Milik Daerah dalam mewujudkan akuntabilitas di BPKAD Kota Madiun. Metode yang digunakan dalam penelitian ini adalah pendekatan kualitatif dengan melakukan wawancara kepada pegawai di bidang akuntansi dan aset. Hasil penelitian menunjukkan bahwa pengamanan Barang Milik Daerah di BPKAD Kota Madiun sudah efektif namun belum akuntabel. Keterbaruan dari penelitian ini yang membedakannya dari penelitian sebelumnya yaitu peneliti memasukkan unsur Pendapatan Asli Daerah (PAD) untuk menilai akuntabilitas dalam pengamanan Barang Milik Daerah.
\end{abstract}

Kata Kunci Pengamanan Barang Milik Daerah; Pendapatan Asli Daerah; Akuntabilitas.

\section{ABSTRACT}

This research aims to analyze and describe the implementation of Regional Property security in realizing accountability in BPKAD of Madiun City. The method uses in this research is qualitative approach by interviews with employees in the field of accounting and assets. The result shows that the Regional Property security in BPKAD Kota Madiun was effective but was not accountable yet. The newness that made this research different from previous research was researcher added Native Revenue (PAD) to assessed accountability in securing Possession of the region.

Keywords: $\quad$ Regional Property Security; Regional Original Income; Accountability.

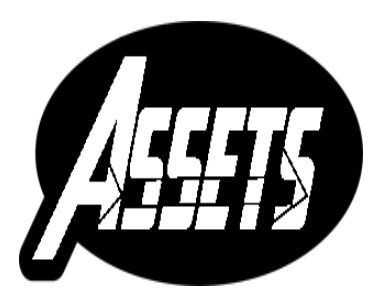

ASSETS

Jurnal Akuntansi dan Pendidikan

Vol. 8 No. 1

Hlmn. 47 - 56

Madiun, April 2019

p-ISSN: 2302-6251

e-ISSN: 2477-4995

Artikel masuk:

9 Maret 2019

Tanggal diterima: 30 April 2019 


\section{PENDAHULUAN}

Semenjak direvisinya Undang-undang Nomor 23 tahun 2004 menjadi Undangundang No. 32 tahun 2014 tentang Pemerintahan Daerah mengakibatkan terjadinya perubahan penyelenggaraan sistem pemerintahan dari sentralistik menjadi desentralistik, sehingga diperlukan suatu manajemen pemerintahan daerah. Manajemen pemerintahan daerah yang efektif diperlukan agar segala urusan pemerintahan yang kewenangannya telah dilimpahkan kepada daerah dapat diselenggarakan secara maksimal dan bisa dipertanggungjawabkan kepada publik. Salah satu bentuk pertanggungjawaban kepada publik adalah pertanggungjawaban atas Barang Milik Daerah.

Peningkatan pentingnya pertanggungjawaban terhadap Barang Milik Daerah didasari oleh Peraturan Pemerintah Nomor 58 Tahun 2005 tentang Pengelolaan Keuangan Daerah mengharuskan penyampaian pertanggungjawaban atas pelaksanaan APBD dalam bentuk laporan keuangan yang disusun melalui suatu proses akuntansi atas transaksi keuangan. Barang Milik Daerah berkaitan dengan pos persediaan, aset tetap dan aset lainnya dalam laporan keuangan. Untuk itu diperlukan khusus dari pemerintah daerah. Tentu tidak berlebihan bila melihat kontribusi pengelolaan Barang Milik Daerah bagi jalannya roda pemerintahan, pelayanan kepada masyarakat, dan salah satu acuan yang digunakan oleh Badan Pemeriksa Keuangan (BPK) dalam pemberian opini.

Kendala yang kerap dihadapi oleh pemerintah daerah dalam pelaksanaan pengamanan Barang Milik Daerah selain terbatasnya sumber daya manusia yang ahli/terlatih adalah belum tegasnya penerapan aturan perundang-undangan terkait. Hal tersebut mengakibatkan munculnya berbagai permasalahan dalam pengamanan Barang Milik Daerah. Beberapa permasalahan diantaranya belum bersertifikatnya aset tanah atau aset tanah sudah bersertifikat namun belum atas nama pemerintah daerah, aset diklaim pihak lain, aset yang tidak diketahui keberadannya, serta lambannya penyelesaian dokumen kepemilikan aset (Lukito, 2017).

Pengamanan Barang Milik Daerah di Kota Madiun memiliki dasar hukum berupa Peraturan Daerah (Perda) Kota Madiun Nomor 08 Tahun 2015 tentang Pengelolaan Barang Milik Daerah, Peraturan menteri dalam Negeri Nomor 19 Tahun 2016 tentang Pedoman Pengelolaan Milik Daerah, dan Peraturan Pemerintah Nomor 27 Tahun 2014 tentang Pengelolaan Barang Milik Negara/Daerah. Pada Peraturan Daerah (Perda) Nomor 08 Tahun 2015 Pasal 1 Ayat (8) disebutkan bahwasanya Barang Milik Daerah, merupakan semua barang yang dibeli atau diperoleh atas beban Anggaran Pendapatan dan Belanja Daerah (APBD) atau perolehan lainnya yang sah.

Kota Madiun adalah kota yang mempunyai beragam aset baik yang berasal dari APBD ataupun perolehan lainnya yang sah. Perolehan lainnya yang sah dapat berasal dari hibah masyarakat atau hibah Pemerintah Pusat. BPKAD Kota Madiun (2017:34), menyebutkan pada tahun 2016 nilai aset Kota Madiun meningkat secara signifikan yaitu Rp2.682.479,66 (dalam jutaan) karena terdapat pelimpahan aset dari Sri Ratu yang telah jatuh tempo masa kontraknya. Aset yang berada di bawah kewenangan daerah tersebut wajib dikelola secara baik dan benar. Maka dari itu, dibutuhkan sebuah sistem untuk mengelola Barang Milik Daerah agar pemanfaatannya memungkinkan untuk memberikan kontribusi yang dapat menaikkan Pendapatan Asli Daerah (PAD).

Meningkatnya pendapatan asli daerah sebagai hasil dari pemanfaatan Barang Milik Daerah diharapkan dapat memberikan kontribusi positif terhadap pembangunan infrastruktur secara berkelanjutan. Selain itu kontribusi Barang Milik Daerah terhadap pendapatan asli daerah dapat juga digunakan sebagai salah satu tolok ukur dalam 
menilai akuntabilitas pemerintah daerah dalam mengelola kekayaan daerah. Berdasarkan Permendagri Nomor 19 tahun 2016 tentang Pedoman Pengelolaan Barang Milik Daerah, bentuk pemanfaatan Barang Milik Daerah diantaranya dalam bentuk sewa, pinjam pakai, kerjasama pemanfaatan, bangun guna serah, dan kerjasama penyediaan infrastruktur.

Apabila pemerintah daerah dalam hal ini BPKAD Kota Madiun tidak mengamankan Barang Milik Daerah yang berpotensi, maka pengelolaan tidak akan efektif dan efisien. Sehingga perlu dilakukan pengamanan terhadap Barang Milik Daerah baik dari segi administrasi, fisik, maupun hukum agar pemanfaatan Barang Milik Daerah dapat dioptimalkan serta menghindarkannya dari diserobot, diambil alih, atau diklaim oleh pihak yang tidak bertanggungjawab (Fuady, 2017).

Pelaksanaan APBD Kota Madiun tahun 2017 memperoleh opini Wajar Tanpa pengecualian (WTP) dari Badan Pemeriksa Keuangan (BPK), menurut Gubernur Jatim Soekarwo perolehan opini WTP ini merupakan perwujudan pengelolaan keuangan yang yang sehat dan juga didukung sistem pengendalian intern yang efektif, serta dipatuhinya peraturan perundang-undangan (Soekarno, 2018). Perolehan opini WTP tersebut tentunya harus terus dipertahankan, salah satunya dengan cara menjaga akuntabilitas pemerintah daerah dalam bidang pengelolaan aset daerah.

Shabrina (2014) menyebutkan bahwa realisasi kegiatan pengamanan aset Pemerintah Kota Surabaya secara administratif, fisik, dan hukum tidak berjalan efektif tapi sudah akuntabel. Tukunang (2016) berpendapat bahwa pengelolaan aset daerah selama ini telah berjalan, namun belum terlaksana sebagaimana yang diharapkan untuk mencapai daya guna dan hasil guna yang maksimal. Sesuai dengan penjabaran di atas, maka penulis tertarik mengambil judul penelitian: Pengamanan Barang Milik Daerah dalam Mewujudkan Akuntabilitas di BPKAD Kota Madiun.

\section{METODE PENELITIAN}

Pada penelitian ini penulis memilih pendekatan penelitian kualitatif dan jenis penelitian deskriptif untuk memaparkan pengamanan Barang Milik Daerah dalam mewujudkan akuntabilitas di BPKAD Kota Madiun. Penelitian ini dilakukan di Badan Pengelolaan Keuangan dan Aset Daerah (BPKAD) Kota Madiun, bagian Akuntansi dan Aset dengan waktu penelitian kurang lebih selama 6 bulan yang dimulai bulan September 2018 hingga bulan Februari 2019. Sumber data berasal dari data primer dan data sekunder yang diperoleh dari hasil wawancara dan dokumentasi.

Data primer diperoleh dari hasil wawancara dengan tiga informan yaitu Kepala Sub Bidang Penatausahaan Aset, Staf Bidang Akuntansi dan Aset, serta Kepala Bidang Akuntansi dan Aset. Peneliti memilih informan berdasarkan topik penelitian dan yang dianggap kredibel untuk menjawab masalah penelitian. Maka dari itu peneliti menetapkan ketiga informan tersebut karena beliau bertiga adalah orang-orang yang terlibat langsung dalam kegiatan pengamanan Barang Milik Daerah.

Adapun data sekunder dalam penelitian ini diperoleh dari catatan-catatan, dokumen-dokumen yang digunakan serta arsip resmi BPKAD Kota Madiun terkait kegiatan pengamanan Barang Milik Daerah selama tahun 2016-2017. Catatan tersebut di ataranya: Standar Operasional Prosedur (SOP) pengamanan Barang Milik Daerah, Kartu Inventaris Barang (KIB), daftar aset tetap Pemerintah Kota Madiun, serta data Realisasi Retribusi Pemakaian Kekayaan Daerah.

Teknik keabsahan data yang digunakan berupa uji credibility (validitas internal) atau kepercayaan terhadap hasil penelitian dengan triangulasi. Triangulasi yang digunakan adalah triangulasi sumber dan triangulasi teknik. Peneliti memilih triangulasi sumber dan teknik dengan alasan efisiensi waktu, sehingga peneliti tidak 
menggunakan triangulasi waktu. Hal ini dikarenakan pada triangulasi waktu membutuhkan wawancara berulangkali yang akan memperlama proses pengumpulan data di lapangan.

\section{HASIL PENELITIAN DAN PEMBAHASAN Pengamanan Barang Milik Daerah}

Shabrina (2014: 4) menjelaskan bahwa pengamanan ialah tindakan mengendalikan serta menertibkan usaha pengurusan Barang Milik Daerah yang terdiri atas pengamanan administrasi, pengamanan fisik, dan pengamanan hukum. Hasil penelitiannya menunjukkan bahwa pengamanan aset Pemerintah Kota Surabaya belum efektif namun sudah akuntabel. Pengamanan aset milik Pemerintah Kota Surabaya dikatakan belum efektif karena belum mampu mencapai sasaran keberhasilan yang diharapkan, baik dari segi pengamanan administrasi, pengamanan fisik, maupun pengamanan hukum (Shabrina, 2014: 6).

Kondisi tersebut bertolak belakang dengan hasil penelitian yang ditemukan oleh peneliti, di mana berdasarkan wawancara yang dilakukan peneliti kepada para informan yang bertugas serta melalui pengumpulan dokumen yang berkaitan dengan pengamanan Barang Milik Daerah diperoleh hasil bahwa pengamanan Barang Milik Daerah, meliputi pengamanan administrasi, pengamanan fisik, dan pengamanan hukum yang dilakukan oleh BPKAD Kota Madiun sudah berjalan secara efektif namun belum akuntabel.

Berikut kutipan wawancara dengan para informan terkait mekanisme pengamanan Barang Milik Daerah oleh BPKAD Kota Madiun. Menurut pernyataan dari para informan, pengamanan Barang Milik Daerah oleh BPKAD Kota Madiun dapat dikatakan sudah efektif dilihat dari telah dilaksanakannya kegiatan pengamanan Barang Milik Daerah sesuai dengan peraturan perundang-undangan yang berlaku. Pernyataan dari Kepala Sub Bidang Penatausahaan Aset adalah sebagai berikut:

"Terkait dengan landasan hukum kita pakai 3 (tiga) landasan hukum. Yang pertama Peraturan Pemerintah PP Nomor 27 Tahun 2014 tentang Pengelolaan Barang Milik Negara/Daerah, kemudian lebih spesifik lagi kita punya perda kota madiun Peraturan Daerah Kota Madiun Nomor 08 Tahun 2015 tentang Pengelolaan Barang Milik Daerah, kemudian terkait dengan perincian pelaksanaan teknis pelaksanaan kita mengacu pada Permendagri Nomor 19 Tahun 2016 tentang Pedoman Pengelolaan Barang Milik Daerah."

Pernyataan senada juga diungkapkan oleh Staf Bidang Akuntansi dan Aset:

"Kalau landasan hukumnya kita menggunakan Permendagri Nomor 19 Tahun 2016 tentang Pengelolaan Barang Milik Daerah, kemudian itu ada turunannya Perda Nomor 08 tahun 2015."

Demikian juga pernyataan dari Kepala Bidang Akuntansi dan Aset:

"Ya untuk pengamanan itu prinsipnya kita ada Permendagri Nomor 19 Tahun 2016 tentang Pedoman Pengelolaan Barang Milik Daerah, kemudian ada Perda Nomor 8 tahun 2015. Jadi permendagri itu acuan dari pusatnya, kemudian untuk muatan lokalnya tadi Perda Nomor 8 tahun 2015." 
Pengamanan administrasi merupakan kegiatan pengendalian dalam pengurusan Barang Milik Daerah dengan menghimpun, mencatat, dan menyimpan bukti kepemilikan atas barang dengan tertib dan aman. BPKAD Kota Madiun telah melakukan kegiatan pengamanan administrasi sesuai dengan peraturan perundangundangan yang berlaku. Di mana kegiatan pengamanannya meliputi kegiatan: 1) penghimpunan, pencatatan, dan penyimpanan seluruh bukti kepemilikan atas aset dengan tertib dan aman; serta 2) melakukan inventarisasi Barang Milik Daerah setiap 5 tahun sekali untuk mengetahui kondisi yang sebenarnya atas Barang Milik Daerah. Kegiatan pengamanan administrasi yang dilakukan BPKAD Kota Madiun tersebut telah sesuai dengan Peraturan Pemerintah Nomor 27 Tahun 2014 tetang Pengelolaan Barang Milik Negara/Daerah Pasal 44 ayat (1); Peraturan Menteri dalam Negeri Nomor 19 Tahun 2016 tentang Pedoman Pengelolaan Barang Milik Daerah; serta Peraturan Daerah Kota Madiun Nomor 08 Tahun 2015 Pasal 40 ayat (1).

Pengamanan fisik merupakan kegiatan yang dikerjakan agar secara fisik Barang Milik Daerah terhindarkan dari persoalan menurunnya fungsi dan jumlah barang, hingga kehilangan barang. Pengamanan fisik Barang Milik Daerah di BPKAD Kota Madiun meliputi: 1) Untuk aset tanah pengamanan dilakukan dengan pemasangan pagar pembatas, pemasangan patok atau prasati, pemasangan papan nama, serta melakukan penjagaan bila diperlukan; 2) Untuk pengamanan fisik terhadap gedung dan bangunan dilakukan dengan cara memasang pagar, memasang bukti kepemilikan, memasang CCTV, dan menyediakan satuan pengamanan (bekerjasama dengan Satpol PP); dan 3) Untuk aset kendaraan dinas pengamanan fisik dilakukan dengan mewajibkan pihak pengguna/peminjam kendaraan dinas membuat surat pernyataan tanggungjawab risiko. Kegiatan pengamanan fisik tersebut sesuai dengan Peraturan Menteri Dalam Negeri Nomor 19 Tahun 2016 tentang Pedoman Pengelolaan Barang Milik Daerah Pasal 299 ayat (1), Pasal 303 ayat (1), dan Pasal 305 ayat (2).

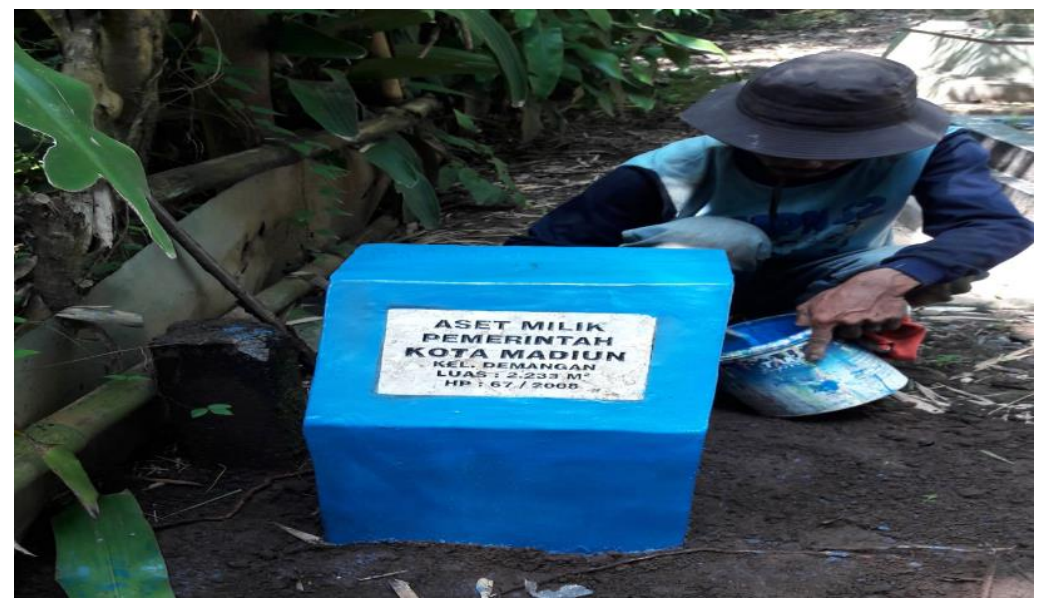

Gambar 1. Kegiatan Pemasangan Patok pada Aset Tanah Pemerintah Kota Madiun

Pengamanan hukum merupakan tindakan pengamanan yang dilakukan terhadap Barang Milik Daerah yang bermasalah dengan pihak lain. Di mana pengamanan hukum yang dilakukan oleh BPKAD Kota Madiun meliputi: 1) pengamanan hukum untuk aset tanah dilakukan dengan pembuatan sertifikat tanah, sedangkan untuk tanah yang sudah bersertifikat namun belum beratasnama pemerintah daerah maka dilakukan pensertifikatan ulang; 2) pengamanan hukum terhadap gedung dan bangunan dilakukan melalui pelengkapan Izin Mendirikan Bangunan (IMB); dan 3) melakukan pengamanan hukum terhadap kendaraan dinas dengan melengkapi Bukti Pemilikan Kendaraan Bermotor (BPKB). Kegiatan 
pengamanan hukum yang dilakukan BPKAD Kota Madiun telah sesuai dengan Peraturan Pemerintah Nomor 27 Tahun 2014 tentang Pengelolaan Barang Milik Negara/Daerah Pasal 43 ayat (1), ayat (2), dan ayat (4); Peraturan Menteri Dalam Negeri Nomor 19 Tahun 2016 tentang Pedoman Pengelolaan Barang Milik Daerah Pasal 308 ayat (2); dan Peraturan Daerah Kota Madiun Nomor 08 Tahun 2015 tentang Pengelolaan Barang Milik Daerah Pasal 39 ayat (1), ayat (2), dan ayat (3). Hal ini sesuai dengan hasil wawancara dengan beberapa pihak. Kepala Sub Bidang Penatausahaan Aset menyebutkan bahwa:

"Kalau pengamanan hukum ini kita melengkapi bukti kepemilikan atas tanah, jadi sertifikat tanah yang belum memiliki sertifikat dan tanah yang belum beratasnama pemerintah kota madiun kita sertifikatkan untuk pengamanan terhadap tanah. Kalau pengamanan terhadap gedung dan tanah seperti tadi ada IMB, kalau hukum terkait dengan bukti kepemilikan."

Pernyataan tersebut didukung dengan pernyataan dari Kepala Bidang Akuntansi dan Aset:

“...kemudian ada pengamanan yang sifatnya legal, contohnya pengamanan dalam bentuk pensertifikatan tanah."

Kegiatan pengamanan Barang Milik Daerah yang dilakukan oleh BPKAD Kota Madiun dikatakan efektif karena telah dilakukan sesuai dengan peraturan perundangundangan yang berlaku yaitu, Peraturan Pemerintah Nomor 27 Tahun 2014 tentang Pengelolaan Barang Milik Negara/Daerah, Peraturan Menteri Dalam Negeri Nomor 19 Tahun 2016 tentang Pedoman Pengelolaan Barang Milik Daerah, dan Peraturan Daerah Kota Madiun Nomor 08 Tahun 2015 tentang Pengelolaan Barang Milik Daerah. Indikator lain yang dapat dijadikan sebagai tolok ukur efektivitas pengamanan Barang Milik Daerah yang dilakukan BPKAD Kota Madiun juga dapat dilihat dari pencapaian target jumlah barang yang telah diamankan hingga mencapai $90 \%-100 \%$ pada setiap tahun anggaran. Hal ini didukung oleh pernyataan dari Kepala Bidang Akuntansi dan Aset:

"Targetnya itu alhamdulillah sudah terpenuhi setiap tahunnya, karena kan memang kita melakukan itu dulu apa ya namanya melihat dari data survey juga sebelumnya gitu jadi alhamdulillah targetnya selalu terpenuhi. Insyaallah 90\% dari target sampai 100\%, karena kan 90\% nya itu ada harga anggaran kemudian realisasinya bisa jadi harganya lebih rendah dibandingkan anggarannya, seperti itu. Tapi kalau melihat jumlah insyallah 100\% sudah terpenuhi targetnya."

Pernyataan beliau tersebut didukung oleh pernyataan dari Staf Bidang Akuntansi dan Aset:

"Ya untuk target insyallah untuk target sudah tercapai ya, karena memang kita setiap tahun menggali data aset-aset yang belum tersertifikat. Ya sekitar $90 \%$ an lebih lah, saya data persis e nggak hafal e mbak."

\section{Kendala dan Solusi dalam Pengamanan Barang Milik Daerah}

Dalam melakukan kegiatan pengamanan Barang Milik Daerah, BPKAD Kota Madiun juga mengalami banyak kendala dalam pelaksanaannya. Kendala tersebut terjadi pada setiap jenis pengamanan, baik pengamanan administrasi, pengamanan 
fisik, dan juga pengamanan hukum. Akan tetapi dengan selalu melakukan koordinasi baik dengan pihak internal maupun eksternal, maka BPKAD Kota Madiun hampir selalu mampu menemukan solusi atas setiap kendala yang terjadi terkait pengamanan Barang Milik Daerah. Kendala dan solusi yang dilaksanakan BPKAD Kota Madiun dipaparkan sebagai berikut.

Kendala dalam pengamanan administrasi meliputi kurang lengkap dan kurang informatifnya catatan atas Barang Milik Daerah sehingga menimbulkan kerancuan bagi pihak-pihak yang memerlukan informasi, serta kurangnya kompetensi dari pegawai yang bersangkutan dalam mengoperasikan aplikasi yang digunakan untuk inventarisasi aset, yaitu aplikasi SIMDA BMD. Solusi yang diterapkan BPKAD Kota Madiun untuk mengatasi kendala tersebut yaitu melakukan rekonsiliasi atas Barang Milik Daerah yang tercatat dalam aplikasi SIMDA BMD dengan data/catatan yang ada, dan juga mengirimkan pegawainya untuk meminta bimbingan langkah penggunaan aplikasi kepada Badan Pengawas Keuangan dan Pembangunan (BPKP) Jawa Timur yang ada di Sidoarjo.

Berikutnya yaitu kendala dalam pengamanan fisik Barang Milik Daerah yaitu adanya penyerobotan aset pemerintah daerah oleh pihak yang tidak bertanggungjawab. Pihak-pihak yang tidak bertanggunjawab tersebut membangun bangunan permanen di atas tanah milik pemerintah daerah, sehingga menimbulkan dilema bagi pemerintah daerah untuk melakukan penggusuran ataukah tidak. Solusi dari permasalahan tersebut terdiri dari berbagai langkah karena memang penanganannya membutuhkan pemikiran yang matang. Solusi yang telah dilakukan dengan oleh BPKAD Kota Madiun yaitu memberikan sosialisasi kepada pihak-pihak yang melakukan penyerobotan, pemasangan papan nama, berkoordinasi dengan pihak-pihak terkait, melakukan relokasi, dan bekerjasama dengan Satpol PP selaku aparat penegak peraturan daerah. Jalil (2018), memaparkan bahwa sejauh ini Pemerintah Kota Madiun berusaha mengajak masyarakat yang menempati aset pemerintah untuk pindah ke rumah susun sederhana sewa (rusunawa) di Kelurahan Nambangan Lor, Kecamatan Manguharjo, Kota Madiun.

Terkait kendala yang terjadi selama dilakukannya pengamanan hukum yaitu masih ada beberapa Barang Milik Daerah yang belum tersertifikat atau sudah tersertifikat namun belum atas nama pemerintah daerah. kendala tersebut terjadi dikarenakan terbatasnya anggaran untuk pembuatan sertifikat setiap tahunnya, sehingga kegiatan pengamanan hukum atas Barang Milik Daerah dilakukan secara bertahap. Mengatasi kendala tersebut langkah yang ditempuh BPKAD Kota Madiun yaitu melakukan pendataan terhadap Barang Milik Daerah yang masih bermasalah agar dapat diurus sertifikatnya, serta selalu menganggarkan biaya untuk pensertifikatan setiap tahunnya.

Kemampuan BPKAD Kota Madiun dalam mengatasi setiap kendala yang terjadi sehubungan dengan kegiatan pengamanan Barang Milik Daerah baik pengamanan administrasi, pengamanan fisik, dan pengamanan hukum berbanding terbalik dengan hasil penelitian yang dilakukan oleh Shabrina. Di mana pada penelitiannya Shabrina memaparkan bahwa pengamanan aset oleh Pemerintah Kota Surabaya masih menemui berbagai kendala dikarenakan kurangnya kualitas sumber daya manusia yang menimbulkan tidak efektifnya pengamanan aset (Shabrina, 2014: 8). Hasil penelitian ini juga berbanding terbalik dengan penelitian yang dilakukan oleh Pradhika (2017), di mana hasil penelitiannya menunjukkan bahwa pengamanan aset oleh Pemerintah Kota Bandung baik pengamanan administrasi, fisik, maupun hukum belum berjalan secara efektif. 


\section{Akuntabilitas}

Terkait dengan akuntabilitas, hasil penelitian yang dilakukan oleh Shabrina kembali bertolak belakang dengan hasil penelitian yang diperoleh peneliti. Shabrina (2014: 6) menyatakan bahwa kegiatan pengamanan aset Pemerintah Kota Surabaya belum efektif secara administrasi, fisik, dan hukum, namun sudah akuntabel. Pada penelitiannya, Shabrina (2014) menggunakan akuntabilitas publik menurut Mardiasmo sebagai dasar penelitian, sedangkan peneliti mendasarkan akuntabilitas dalam penelitian ini selain pada akuntabilitas publik menurut Mardiasmo, peneliti juga melihat ada tidaknya kontribusi Barang Milik Daerah terhadap pendapatan asli daerah untuk melihat apakah BPKAD Kota Madiun sudah akuntabel atau belum.

\section{Akuntabilitas Publik}

Akuntabilitas yang dimaksud dalam penelitian ini adalah akuntabilitas publik menurut Ellwood (1993), di mana akuntabilitas tersebut terdiri dari 4 (dimensi), yaitu akuntabilitas kejujuran dan hukum, akuntabilitas proses, akuntabilitas program, dan akuntabilitas kebijakan, serta dengan melihat ada tidaknya kontribusi dari pemanfaatan Barang Milik Daerah yang telah diamankan terhadap pendapatan asli daerah.

Pelaksanaan pengamanan Barang Milik Daerah oleh BPKAD Kota Madiun telah memenuhi semua aspek akuntabilitas publik. Akuntabilitas kejujuran dan akuntabilitas hukum dibuktikan dengan adanya pemisahan wewenang dalam kegiatan pengamanan Barang Milik Daerah, sedangkan untuk akuntabilitas hukumnya dapat dilihat dari telah sesuainya mekanisme pengamanan Barang Milik Daerah yang dijalankan dengan SOP dan peraturan perundang-undangan yang berlaku. Akuntabilitas proses tercermin dari adanya kejelasan sistem informasi dalam pencatatan Barang Milik Daerah. Dalam hal ini informasi atas Barang Milik Daerah tercantum pada Kartu Inventaris Barang (KIB). Akuntabilitas program yaitu telah tercapainya target atas Barang Milik Daerah yang harus diamankan, dengan angka pencapaian sebesar 90\% - 100\% pada setiap tahun anggaran, dan akuntabilitas kebijakan dibuktikan dengan telah dilakukannya pertanggungjawaban secara tertulis oleh BPKAD Kota Madiun kepada Walikota dan DPRD Kota Madiun. Dari penjabaran empat unsur dalam akuntabilitas publik tersebut dapat diketahui bahwa BPKAD Kota Madiun telah memenuhi unsur akuntabilitas publik.

\section{Kontribusi Barang Milik Daerah terhadap Pendapatan Asli Daerah}

Akuntabilitas BPKAD Kota Madiun dalam mengamankan Barang Milik Daerah selain dilihat dari terpenuhinya 4 aspek akuntabilitas publik di atas, juga dilihat dari ada tidaknya kontribusi dari Barang Milik Daerah tersebut terhadap pendapatan asli daerah sebagai hasil dari pemanfaatan Barang Milik Daerah tersebut. Bentuk pemanfaatan atas Barang Milik Daerah oleh BPKAD Kota Madiun meliputi kerjasama sewa, kerjasama pemanfaatan (KSP), dan Bangung Guna Serah (BGS).

Kerjasama sewa merupakan kegiatan pemanfaatan atas Barang Milik Daerah oleh pihak lain dalam waktu tertentu dengan imbal hasil berupa uang tunai. Data yang telah diperoleh peneliti menunjukkan adanya kontribusi atas Barang Milik Daerah terhadap pendapatan asli daerah dari hasil kerjasama sewa. Kontribusi Barang Milik Daerah terhadap pendapatan asli daerah dari hasil kerjasama sewa disajikan pada tabel 1. Dari tabel tersebut dapat dilihat bahwa pada tahun 2017 imbal hasil yang diperoleh dari pemanfaatan Barang Milik Daerah dalam bentuk kerjasama sewa menunjukkan adanya peningkatan dari tahun 2016 sebesar $\mathrm{Rp}$ 4.185.793.881,-Peningkatan perolehan retribusi pemakaian kekayaan daerah pada tahun 2017 
diperoleh dari kenaikan signifikan atas sewa tanah serta kenaikan signifikan atas sewa gedung dan bangunan.

Tabel 1. Realisasi Retribusi Pemakaian Kekayaan Daerah Tahun 2016-2017

\begin{tabular}{lrr}
\hline \multicolumn{1}{c}{ Uraian } & \multicolumn{2}{c}{ Total Realisasi } \\
\hline & Tahun 2016 & \multicolumn{1}{c}{ Tahun 2017 } \\
\hline Retribusi sewa tanah & 1.020 .135 .325 & 2.731 .432 .873 \\
\hline Retribusi sewa gedung dan bangunan & 1.177 .470 .377 & 3.555 .098 .710 \\
\hline Retribusi sewa kios & 379.258 .990 & 476.126 .990 \\
\hline Total & $\mathbf{2 . 5 7 6 . 8 6 4 . 6 9 2}$ & $\mathbf{6 . 7 6 2 . 6 5 8 . 5 7 3}$ \\
\hline
\end{tabular}

Sumber: BPKAD Kota Madiun

Bentuk pemanfaatan atas Barang Milik Daerah yang dilaksanakan oleh BPKAD Kota Madiun yang kedua yaitu pemanfaatan dalam bentuk Kerjasama Pemanfaatan (KSP). Kerjasama Pemanfaatan (KSP) merupakan pendayagunaan Barang Milik Daerah oleh pihak lain dalam waktu tertentu dengan maksud untuk meningkatkan pendapatan asli daerah maupun sumber pembiayaan lainnya. Barang Milik Daerah yang dimanfaatkan untuk Kerjasama Pemanfaatan (KSP) adalah kerjasama terkait Plaza Lawu yang dipercayakan pengelolaannya kepada pihak ketiga karena pemerintah daerah mengalami kesulitan dalam mengelolanya. Data terkait berapa jumlah pasti imbal hasil yang diterima oleh pemerintah Kota Madiun dari kerjasama pemanfaatan (KSP) Plaza Lawu tersebut tidak berhasil peneliti peroleh. Rincian data yang diberikan oleh pihak BPKAD Kota Madiun hanya terbatas pada rincian data pemanfaatan Barang Milik Daerah dalam bentuk kerjasama sewa.

Bentuk pemanfaatan Barang Milik Daerah berikutnya berupa Bangun Guna Serah (BGS). Bangun Guna Serah (BGS) merupakan kegiatan pemanfaatan Barang Milik Daerah berwujud tanah oleh pihak lain melalui pendirian bangunan maupun sarana beserta prasarana, untuk selanjutnya diberdayakan dengan jangka waktu sesuai kesepakatan bersama. Di mana ketika telah habis jangka waktu yang telah disepakati maka akan dikembalikan tanah beserta bangunan termasuk sarana dan prasarana di dalamnya kepada pemerintah daerah. Berdasarkan pernyataan dari Kepala Sub Bidang Pendayagunaan Aset, contoh pemanfaatan Barang Milik Daerah dalam bentuk Bangun Guna Serah yaitu kerjasama aset Sun City Kota Madiun yang berlangsung selama 30 tahun, di mana nanti ketika telah berakhir masa perjanjian maka Sun City beserta segala fasilitas yang ada di dalamnya akan diserahkan kepada pemerintah daerah Kota Madiun.

Senada dengan data terkait pemanfaatan barang Milik daerah dalam bentuk kerjasama pemanfaatan (KSP), untuk Bangun Guna Serah (BGS) ini data yang diperoleh peneliti juga hanya terbatas pada jenis Barang Milik Daerah yang dimanfaatkan dan jangka waktu pemanfaatannya, yaitu berupa Sun City Kota Madiun dengan jangka waktu selama 30 tahun. Sedangkan untuk data rincian perolehan imbal hasil atas Bangun guna Serah (BGS) tersebut tidak berhasil peneliti dapatkan.

\section{SIMPULAN}

Berdasarkan hasil penyajian dan analisis data yang dilakukan, maka simpulan yang dipaparkan pada penelitian ini yaitu, pelaksanaan pengamanan Barang Milik Daerah meliputi pengamanan administrasi, pengamanan fisik, dan pengamanan hukum yang dilakukan BPKAD Kota Madiun sudah efektif. Pelaksanaan pengamanan Barang Milik Daerah oleh BPKAD Kota Madiun belum akuntabel. Hal ini dikarenakan akuntabilitas yang terpenuhi hanya berupa akuntabilitas publik yang meliputi 
akuntabilitas hukum dan kejujuran, akuntabilitas proses, akuntabilitas program, dan akuntabilitas kebijakan.

Keterbatasan dalam penelitian ini yaitu tidak diperolehnya data terkait nominal imbal hasil yang didapatkan oleh BPKAD Kota Madiun dari kegiatan pemanfaatan Barang Milik Daerah dalam bentuk Kerjasama Pemanfaatan (KSP) dan Bangun Guna Serah (BGS), sehingga peneliti tidak dapat menjabarkan secara jelas berapa kontribusi dari pemanfaatan Barang Milik Daerah terhadap Pendapatan Asli Daerah. Sebaiknya BPKAD Kota Madiun menggunakan aplikasi SIMDA Pendapatan dalam pengelolaan dan penatausahaan pendapatan asli daerah yang mendukung penyediaan dan penyajian data realisasi pendapatan asli daerah secara akurat dan menyeluruh.

\section{DAFTAR PUSTAKA}

BPKAD Kota Madiun. (2017). Renstra BPKAD Kota Madiun Tahun 2014-2019. Madiun: Badan Pengelolaan Keuangan dan Aset Daerah Kota Madiun.

Ellwood, S. (1993). Parish Town and Councils. Financial Accountability and Management Local Government Studies, 19, 368-386.

Fuady, M.M. (2017). Kegiatan Pengamanan Barang Milik Daerah. Diakses pada 15 Desember 2018, dari http://bpkad.banjarkab.go.id/index.php/2017/02/06/kegiatan-pengamananbarang-milik-daerah/.

Jalil, A. (2018). 200 Rumah Warga Tempati Lahan Milik Pemkot Madiun. Diakses pada 25

Maret 2019 dari

https:/ / m.solopos.com/madiun/read/20180419/911440/200-rumah-wargatempati-lahan-milik-pemkot-madiunn\#\&gid=1\&pid=1.

Lukito, J. (2017). Identifikasi Masalah aset Berdasar Riset dan Hasil Pemeriksaan BPK. Diakses pada 6 Desember 2018, dari https:/ / www.djkn.kemenkeu.go.id.

Mardiasmo. (2009). Akuntansi Sektor Publik. Yogyakarta: Andi.

Peraturan Daerah Kota Madiun Nomor 08 Tahun 2015 Tentang Pengelolaan Barang Milik Daerah.

Peraturan Menteri Dalam Negeri Nomor 19 Tahun 2016 tentang Pedoman Pengelolaan Barang Milik Daerah.

Peraturan Pemerintah Nomor 58 Tahun 2005 tentang Pengelolaan Keuangan Daerah.

Peraturan Pemerintah Nomor 27 Tahun 2014 tentang Pengelolaan Barang Milik Negara/Daerah.

Pradhika, I. (2017). Analisis Efektivitas Pengamanan Aset dalam Mewujudkan Akuntabilitas Publik (Studi Pada Badang Pengelolaan Keuangan dan Aset Kota Bandung. Skripsi. Politeknik Negeri Bandung.

Soekarno, R. (2018). Pemprov Jatim dan 36 Kabupaten/Kota Raih Opini WTP. Diakses pada 4 Desember 2018, dari http://m.beritajatim.com/politik_pemerintahan/340315/pemprov-jatim-dan36-kabupaten/kota_raih-opini-wtp.html.

Shabrina, N. K. (2014). Efektivitas Pengamanan Aset dalam Mewujudkan Akuntabilitas di Pemerintah Kota Surabaya. Jurnal Kebijakan dan Manajemen Publik, 2, 1-9.

Tukunang, S. C. F. (2016). Manajemen Aset Daerah pada Dinas Pendapatan Pengelolaan Keuangan dan Aset Daerah Kabupaten Kepulauan Siau, Tagulandang, Biaro. Jurnal EMBA, 4, 236-253.

Undang-undang Nomor 23 Tahun 2014 tentang Pemerintahan Daerah. 